\title{
茂原型水溶性ガス貯留層における群井系の
}

産出挙動シミュレーション

\author{
秋林 智*・周萍 ${ }^{* *} \cdot$ 湯原 浩三***
}

（昭和63年 1 月 27 日受付, 63 年 3 月 31 日受理）

\section{A Numerical Model for Simulating Production Behavior of Multi-wells in the Mobara-type Water-dissolved Natural Gas Reservoir}

By

Satoshi Akibayashi, Ping ZHou and Kozo YUHARA

\begin{abstract}
This paper describes a simplified three-dimensional numerical model for production behavior of the Mobara-type water-dissolved natural gas reservoir composed of alternating beds of sandstones and mudstones. It is assumed that water and gas flow horizontally through the sand-stones and vertically (in one dimension only) through the mudstones. Finite difference approximation method is used to solve the differential flow equations.

Application of the model to a practical Mobara-type field in Chiba Prefecture shows very good coincidence between the calculated and the measured values for the average gas-waterratio of all the production wells.

Calculation results show that the production behavior remains ordinary-type if gas does not migrate from the mudstones to the sandtones even though pressure is maintained at a constant and a large amount of free gas is supplied at the boundaries, provided that the reservoir be isotropic and homogeneous.
\end{abstract}

\section{1. 緒言}

茂原型水溶性ガス眝留層に扔ける産出挙動を的確に予 測するには，多くの生産井（群井系）が同時に採水を行 う場合の産出挙動を解明することが重要である。さきに 秋林ら（1985）は，泥岩層がガスのみを含有していると 仮定して，泥岩層からガスの浸出を考慮した水平二次元 モデルにより，茂原型水溶性ガス眝留層における生産井 の相互干渉を定量的に考察した。しかし，実際の茂原型 と呼ばれるガス眝留層の泥岩層にはガスおよび水が共存 していることから，そのようなモデルを用いては茂原型 水溶性ガス眝留首における群井系の産出挙動を十分に表 し得ないと考えられる。

*秋田大学鈗山学部

$* *$ 九州大学工学研究科

***九州大学工学部
本研究は，秋林ら（1985）の水平二次元モデルを泥岩 層内の二相流を考慮したモデルに発展し，実際の産出ガ ス水比のヒストリ・デー夕を用いてモデルの妥当性の検 証を行うと共に, 2 坑の生産井間の相互干渉の問題およ び断層からのガスの供給による影響についても検討した。

\section{2. 数学モデル}

茂原型ガス眝留層の概念モデルを図 1 に示す。眓中に おいて， $H_{s}$ および $H_{m}$ は砂岩層および泥岩層の厚さ， $L_{x}$ 怙よび $L_{y}$ は $x$ および $y$ 方向に㧍ける眝留層の長さ, $N$ は秒岩層むしくは泥岩層の枚数である。数学的に取 り扱いやすくするために，次のような仮定を設ける。

（1）砂岩層㧍上び泥岩層は等方性で，流動に与える眝 留層の圧縮性の影響を無視する。

(2) 砂岩層内におけるガス, 水の流動は水平二相流で あるとし，毛細管圧力および重力の影響を無視する。 


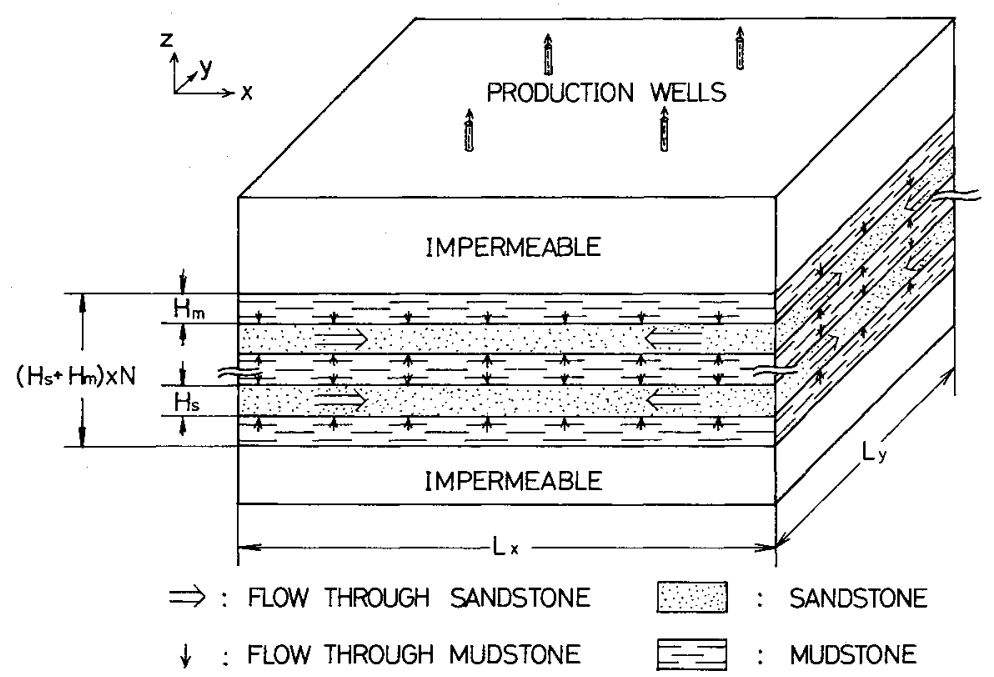

図 1 茂原型ガス眝留層の概念モデル

（3）泥岩層内におけるガス，水の流動は鉛直流のみで あるとする。同様に毛細管圧力および重力の影響を無視 する。

（4）踪留層の孔隙摔, 絶対浸透率, 水の粘性係数など は死力の変化によらず一定とする。

（5）貯留層の温度は一定であり, 水の蒸発および凝縮 は考えないものとし，ガスの成分はメタンのみとする。

上記の仮定(3)はかなり大胆であるように思われるが, 実際のガス詝留層では砂岩層と泥岩愿との絶対浸透率の 差は非常に大きく，両岩層の厚さが共に極めて薄いこ上 から，泥岩首内に扔いては鉛直方向の圧力勾配が水平方 向のそれに比較して遥かに大きいことが解る。したがっ て，泥岩層に扔ける水平流を無視した。

ここで， $R_{s}$ はガスの溶解度， $K a$ は絶対浸透率， $k_{r}$ は相対浸透率， $B$ は流体の容樍係数（眝留層圧力の下で の容積と標準状態における容積の比)， $\mu$ は粘性係数, $p$ は圧力, $S$ は飽和率, $\phi$ は孔隙率, $q$ は単位時間単位 体積あたりの質量浸出量, $\rho$ は標準状態における密度, $t$ およびては砂岩層および泥岩層内の流動方程式におけ る時間，下添え字 $w, g, s, m, b$ ，およびin.はそれ ぞれ水, ガス, 砂岩層, 泥岩層, 境界扎よび初期状態を 表しているとすれば，以上の仮定に基づいて，砂岩層お よび泥岩層内における流動方程式は質量保存則およびダ ルシーの運動方程式により，次のように与えられる。

(1) 砂岩層内における水平二次元流動方程式

ガス: $\left[k_{a s}\left(\lambda_{g}+\lambda_{w} R_{s}\right) \quad p\right]+q_{g} / \rho_{g}$

$$
=\frac{\partial}{\partial t}\left\{\phi_{s}\left(\frac{S_{g}}{B_{g}}+\frac{S_{w}}{B_{w}} R_{s}\right)\right\}
$$

水: $\quad\left(\begin{array}{ll}k_{a s} \lambda_{w} & p\end{array}\right)+q_{w} / \rho_{w}=\frac{\partial}{\partial t}\left\{\frac{\phi_{s} \cdot S_{w}}{B_{w}}\right\} \cdots(2)$ ただし

$$
\begin{aligned}
& \lambda_{w}=K_{r w} /\left(\mu_{w} B_{w}\right) \\
& \lambda_{g}=k_{r g} /\left(\mu_{g} B_{g}\right) \\
& S_{w}=1-S_{g}
\end{aligned}
$$

初期条件 :

$$
\begin{aligned}
t= & 0 \text { のとき : } \\
& p(x, y)=p_{\text {in. }}=\text { const. } \\
& S_{g}(x, y)=S_{\text {gin. }}=\text { const }
\end{aligned}
$$

不透水境界条件：

$$
\left.\begin{array}{l}
x=0, L_{x} \text { において }: \frac{\partial p}{\partial x}=0 \\
y=0, L_{y} \text { において }: \frac{\partial p}{\partial y}=0
\end{array}\right\}
$$

等圧境界条件：

$$
\begin{gathered}
x=0, L_{x} \text { において: } \\
p(0, y)=p\left(L_{x}, y\right)=p_{\text {in. }} \\
S_{g}(0, y)=S_{g}\left(L_{x}, y\right)=S_{g b} \\
y=0, L_{y} \text { において: } \\
p(x, 0)=p\left(x, L_{y}\right)=p_{\text {in. }} \\
S_{g}(x, 0)=S_{g}\left(x, L_{y}\right)=S_{g b}
\end{gathered}
$$

式(1)および式(2)における $q w / \rho_{w} お よ ひ ゙ ~ q g / \rho_{g} は$ 次のように計算される。

生産井のある場所では

$$
\left.\begin{array}{l}
q_{w} / \rho_{w}=q_{w}^{*}+Q_{w^{*}} \\
q_{g} / \rho_{g}=\left(q_{g}{ }^{*}+R_{s} \cdot q_{w}^{*}\right)+Q_{g}{ }^{*}
\end{array}\right\}
$$


生産井のない場所では

$$
\begin{aligned}
& \mathrm{q}_{\mathrm{w}} / \rho_{\mathrm{w}}=\mathrm{qw}^{*} \\
& \mathrm{qg}_{\mathrm{g}} / \rho_{\mathrm{g}}=\mathrm{qg}^{*}+\mathrm{R}_{\mathrm{s}} \cdot \mathrm{qw}^{*}
\end{aligned}
$$

ここで, $q w^{*}, q \mathrm{~g}^{*}$ はそれぞれ単位時間単位体積当た りの水およびガスの体積浸出量, $Q \omega^{*}, Q_{g}{ }^{*}$ はそれぞ れ単位時間単位体積当たりの採水量および採ガス量であ る。 $q w^{*}, q_{g}$ *の定義式は秋林ら（1986）に従った。

（2）泥岩層における流動方程式

$$
\text { ガス: } \frac{\partial}{\partial z}\left\{k_{a m}\left(\lambda_{u m} R_{s}+\lambda_{g m}\right) \frac{\partial p m}{\partial z}\right\}
$$

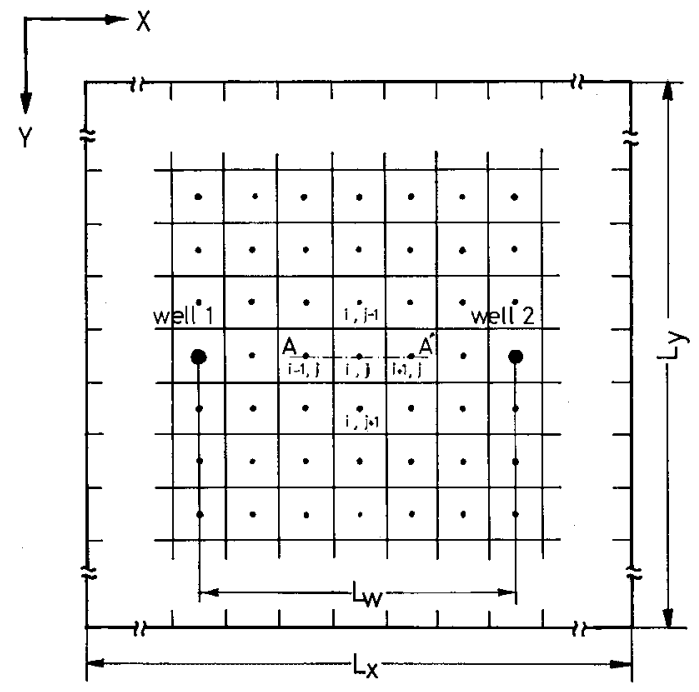

図 2 a 水平二次元差分格子座標系（砂岩層）

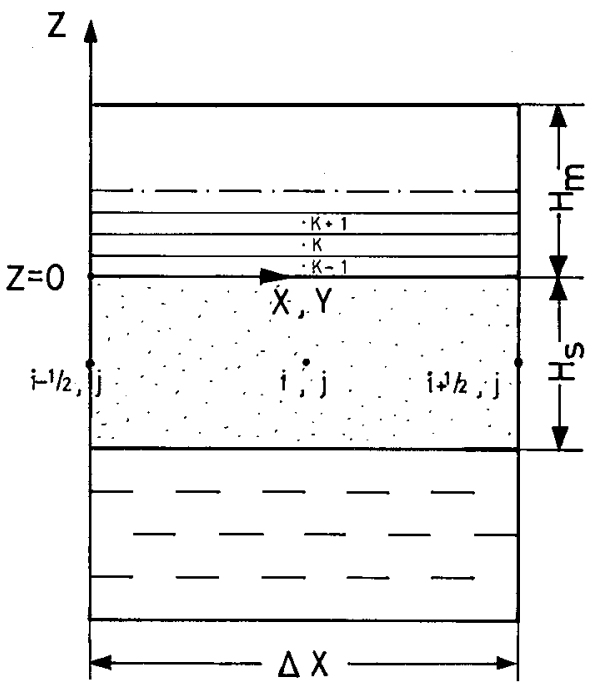

$A-A^{\prime}$. SECTION

図 $2 \mathrm{~b}$ 泥岩層之砂岩層の関係および泥岩層の鉛直差分 格子坐標系

$$
=\frac{\partial}{\partial \tau}\left\{\phi_{m}\left(\frac{S_{g m}}{B_{g m}}+\frac{S_{w m}}{B_{u m}} R_{s}\right)\right\}
$$

$$
\text { 水 : } \frac{\partial}{\partial z}\left\{k_{a m} \lambda u m \frac{\partial p_{m}}{\partial z}\right\}=\frac{\partial}{\partial \tau}\left\{\phi_{m} \frac{S_{u m}}{B_{u m}}\right\} \cdots(10)
$$
ただし

$$
\begin{aligned}
& \lambda_{u m}=k_{r w m} /\left(\mu_{u m} B_{u m}\right) \\
& \lambda_{g m}=k_{r g m} /\left(\mu_{g m} B_{g m}\right) \\
& S_{u m}=1-S_{g m}
\end{aligned}
$$

ここで，原点は各々の泥岩層の下面に置き， $z$ 軸は上 方向を正に取っている（図 2b）。 初期条件 :

$\tau=0$ のとき :

$$
p_{m}=p_{m}(\mathrm{z})
$$

境界条件：

$z=0, H_{m}$ において:

$$
p_{m}=p_{s i, j}
$$

\section{3. 方程式の解法}

式(1), 式(2), 式(9), 式(10)は複雑な非線形偏微分方程式

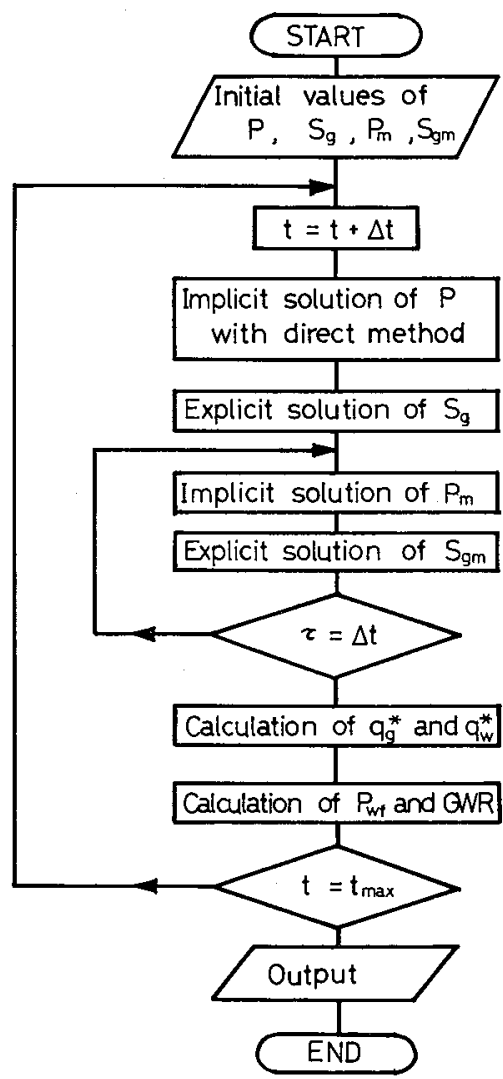

図 3 差分計算フローチャート 
であり，その解析解を求めることが困難であるので，本 研究では差分法を用いて近似的に解くことにした。砂岩 層を図 $2 \mathrm{a}$ に示す水平二次元差分格子座標系で表し，各々 の秒岩層ブロック（i，j）に対応している泥岩層を図 2 b に示す鉛直差分格子座標系で表す。図 2 a において,

$\mathrm{Lw}$ は坑井間隔を表している。

計算手順（図 3 参照）は，基本的には秋林らに従った。 まず時刻 $t=(n+1) \cdot \Delta t(n=0,1,2, \cdots)$ における 砂岩層内の圧力および飽和率分布は, 時刻 $t=n \cdot \Delta t$ に おりるブロック中心 $(i, j)$ の王力および飽和率, ガス および水の体積浸出量を用いて, 境界条件式(5)の下に, 式(1)および(2)を IMPES 法で表した差分式を解いて求め る。次に泥岩層内の圧力および飽和率は, 時刻 $t=(n+$ 1)・ $\Delta t$ の砂岩層の圧力および飽和率を泥岩層之砂岩層 の境界値として固定して, 式(9)および(10)を IMPES 法で 表した差分式を解いて求める。その後で時刻 $\tau=n \cdot \Delta t$ $\sim(n+1) \cdot \Delta t$ の間のガスおよび水の平均体積浸出量 $q g^{*}$ および $q \omega^{*}$ を求める。

以上の計算過程を繰り返して任意の時刻における圧力 および飽和率分布を求めることができる。

坑底压力 $p_{w f}$ は坑井ブロックにおける圧力および飽和 率から, 次のように PEACEMAN (1978) の修正式によっ て求めた。

$$
p_{w f}=p_{s}+\frac{Q_{w} \mu_{w} B w}{2 \pi k_{a s} k_{r w} H_{s}} \ln \frac{r_{w}}{0.2 \Delta x}
$$

ここで， $p_{s}$ は砂岩層ブロックの圧力の差分解，Qwは 坑井の採水量, $P \omega$ は坑井の実際の半径, $\Delta x$ は $x$ 方向 の差分格子間隔 ( $\Delta x=\Delta y$ の正方格子) を表している。 坑井の産出ガス水比 GWR は式(15)によって計算され る。

$$
G W R=R_{s}+\frac{k_{r g} \mu_{w B w}}{k_{r w} \mu_{g} B_{g}}
$$

\section{4. 計算の入カデータ}

表 1 は本計算の入力データを示す。ここで, pin, kas, $k_{a m}, r_{w}, \phi_{s}, \phi_{m}, H_{s}, H_{m}, \mu_{w}$ は干葉県の実際のガ ス田のデータを参考にして与えた（上野他，1964）。こ こで, $S_{w}{ }^{* *}$ は不動水飽和率（岩石内部壁上の濡れ膜や 小孔隙内にある流動できない水の飽和率）とし， $S_{w}{ }^{*}$ はガスが流動できない状態での水の最小飽和率とす る。 $\left(S_{\text {gin. }}\right)_{\mathrm{s}},\left(S_{\text {gin. }}\right)_{m},\left(S_{w^{* *}}\right)_{s},\left(S_{w^{*}}\right)_{m},\left(S_{w^{*}}\right)_{s}$, $\left(S_{w^{*}}^{*}\right)_{m}$ ，などについては測定情報が入手し難いため, 仮定值を用いた。

なお，ガスの粘性係数 $\mu \mathrm{g}$, 純水におけるメタンの溶
表 1 計算の入力データ

\begin{tabular}{|c|c||c|c|}
\hline$p_{i n .}$ & $50 \mathrm{kgf} / \mathrm{cm}^{2 * 1)}$ & $T$ & $20{ }^{\circ} \mathrm{C}$ \\
\hline$\left(S_{g i n .}\right)_{s}$ & 0 & $\left(S_{g i n .}\right)_{m}$ & 0.5 \\
\hline$K_{a s}$ & $40 \mathrm{md}^{* 2)}$ & $K_{a m}$ & $\left.9 \times 10^{-6} \mathrm{md}^{* 2}\right)$ \\
\hline$H_{s}$ & $0.8 \mathrm{~m}$ & $H_{m}$ & $2.2 \mathrm{~m}$ \\
\hline$L_{x,} L_{y}$ & $3000 \mathrm{~m}$ & $\Delta X, \Delta Y$ & $100 \mathrm{~m}$ \\
\hline$\Delta t$ & 5 days & $\Delta z$ & $0.4 \mathrm{~m}$ \\
\hline$\left(S^{*} w\right)_{s}$ & 0.98 & $\left(S^{*} w\right)_{m}$ & 0.60 \\
\hline$\left(S_{w}{ }^{* *}\right)_{s}$ & 0.05 & $\left(S_{w}^{* *}\right)_{m}$ & 0.30 \\
\hline$\phi_{s}$ & 0.23 & $\phi_{m}$ & 0.28 \\
\hline$N$ & 90 & $r_{w}$ & $0.12 \mathrm{~m}$ \\
\hline
\end{tabular}

液度 $R_{s}$ ，ガスを溶解した水の容積係数 $B_{w}$ は，数表 (FRICK，1962；MACAIN，1973）から実際のガス貯留 層の温度 $T=20^{\circ} \mathrm{C}$ （上野他，1964）での值を読み取り， 最小二乗法を用いて整理し，それぞれ次のような圧力 $p$ $\left.\left(\mathrm{kgf} / \mathrm{cm}^{2}\right) * 1\right)$ の関数で近似した。

$\left.\begin{array}{l}\mu_{g}=0.01175-1.6765 \times 10^{-6} \mathrm{p}+2.7268 \times 10^{-17} \mathrm{p}^{2} \mathrm{cp}{ }^{* 3)} \\ R_{s}=0.07124+0.2779 \mathrm{p} \\ B_{w}=1.0178-4.3188 \times 10^{-5} \mathrm{p}+1.8932 \times 10^{-9} \mathrm{p}^{2}\end{array}\right\}$ (16)

水の粘性係数 $\mu_{\omega}$ は, $20^{\circ} \mathrm{C}$, 大気圧での值 $\mu_{w}=1.002$

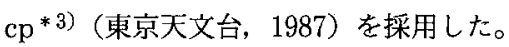

本研究ではガスを理想気体と仮定したことから，ガス の容積係数 $\mathrm{Bg}$ は理想気体状態方程式から次のように与 えた。

$$
B_{g}=P_{a} / P
$$

ここで，Paは標準状態での圧力である。

ガスおよび水の相対浸透率は COREY (1954) に上っ て提案された次式で与えた。

$$
\begin{aligned}
& k_{r w}=\left(\frac{S_{w}-S_{w}^{* *}}{1-S_{w}^{* *}}\right)^{4} \\
& k_{r g}=\left(1-\frac{S_{w}-S_{w}^{* *}}{S_{w}^{*}-S_{w^{* *}}}\right)^{2}\left\{1-\left(\frac{S_{w}-S_{w}^{* *}}{1-S_{w}^{* *}}\right)^{2}\right\}
\end{aligned}
$$

\section{5. 数学モデルの検証}

前述の数学モデルの妥当性を検証するために, 千葉県 にある実際の茂原型ガス田に㧍ける平均産出ガス水比の

*1) $1 \mathrm{kgf} / \mathrm{cm}^{2}=9.807 \times 10^{4} \mathrm{~Pa}$

*2) $1 \mathrm{md}=9.869 \times 10^{-4} \mu \mathrm{m}^{2}$

*3) $1 \mathrm{cp}=10^{-3} \mathrm{~Pa} \cdot \mathrm{S}$ 


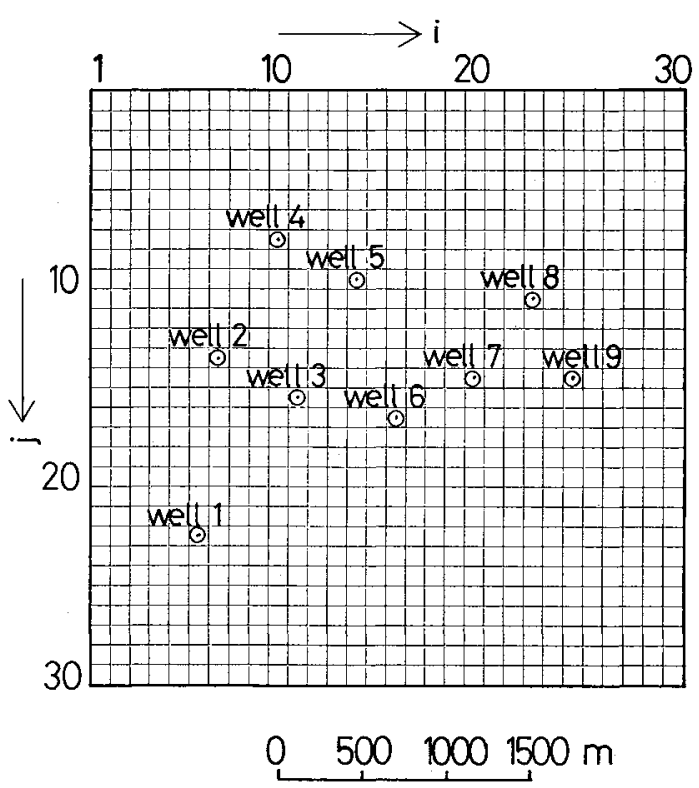

図 4 対象ガス田内の坑井分布

データについてヒストリマッチングを行った。

対象ガス田は約 $3,500 \mathrm{~m} \times 3,500 \mathrm{~m}$ の正方形領域内に あり，その周辺ガス田の生産による影響を受けて境界上 ではガスおよび水の流動がないすのと考えられている。 領域内には合計 9 坑の生産井が掘削されている（図 4 参 照)。これらの坑井の過去 5 年間の月間平均採水量を図 5 に示し，圧力ビルドアップ・テストによって得られた 各坑井周辺の絶対浸透率の值を表 2 に示している。この 表に示されているように当地域内の眝留層は水理的に不 均質である。しかしながら坑井周辺以外の場所における 絶対浸透率等の貯留層パラメータの空間的分布が不明で あることや，眝留層の地下構造および水理的条件につい てまだ十分に解明されていないこと等から，各々の坑井 における産出ガス水比および坑底压力を完全にマッチン グさせることは極めて困難である。そこで本研究では 9 坑井の平均産出ガス水比のみに注目して計算を行った。

差分計算にあたっては，対象領域を図 4 に示すような $30 \times 30(\Delta x=\Delta y=116.67 \mathrm{~m})$ の正方差分格子系で分 割し, 前述の周辺ガス田の影響を考慮して不透水境界条 件（式(5)）を採用した。坑井ブロックに扔ける貯留層の 絶対浸透率は表 2 に示す值を用い，坑井以外のブロック における絶対浸透率の值は表 2 に示す值の平均值を用い た。図 5 に示す過去 5 年間の各坑井の採水寒績を計算に おける採水量の入力值として与えた。

砂岩層の厚さ $H_{s}$ 之泥岩層の厚さ $H_{m}$ （表 3 参照）な どをパラメータとして, それらの值を種々変えて計算を
表 2 压力ビルドアップテストによる各坑井周辺の砂岩 層絶対浸透率

\begin{tabular}{|c|c|c|c|c|c|c|c|c|c|}
\hline Well No. & 1 & 2 & 3 & 4 & 5 & 6 & 7 & 8 & 9 \\
\hline$k_{s}$ (md $\left.{ }^{* 2)}\right)$ & 18.0 & 36.0 & 29.0 & 55.0 & 73.0 & 19.0 & 53.0 & 37.0 & 29.0 \\
\hline
\end{tabular}

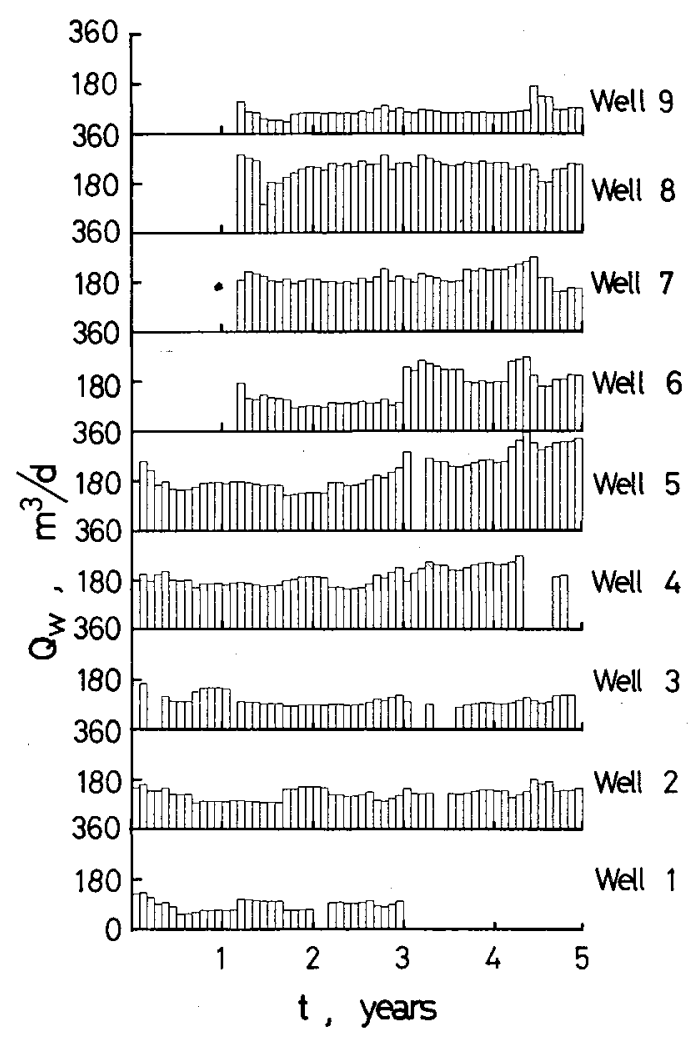

図 5 生産井過去 5 年間の月間平均日採水量

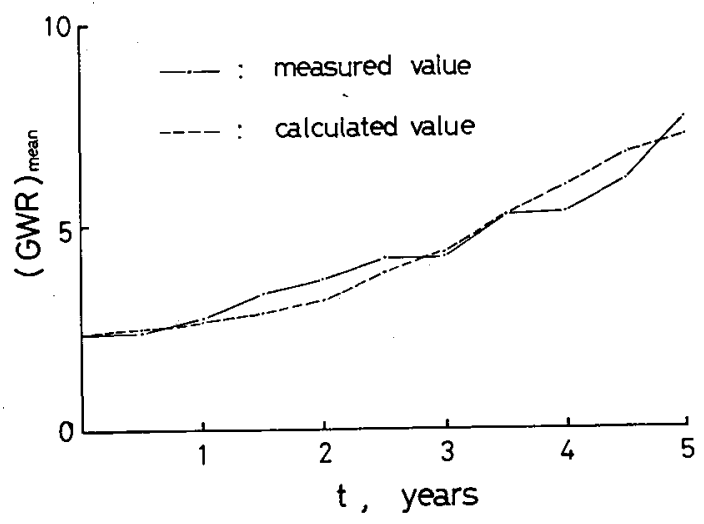

図 6 実測值と計算値の比較 
表 3 計算に用いたパラメータとその範囲

\begin{tabular}{|c|c|c|c|c|c|c|c|}
\hline $\begin{array}{c}H_{s} \\
(\mathrm{~m})\end{array}$ & $\begin{array}{c}H_{m} \\
(\mathrm{~m})\end{array}$ & $\begin{array}{c}\left(S_{\text {gin. }}\right)_{s} \\
\%\end{array}$ & $\begin{array}{c}\left(S_{g i n}\right)_{m} \\
\%\end{array}$ & $\begin{array}{c}\left(S_{w^{*}}\right)_{s} \\
\%\end{array}$ & $\begin{array}{c}\left(S_{w^{*}}\right)_{s} \\
\%\end{array}$ & $\begin{array}{c}\left(S_{w^{*}}\right)_{m} \\
\%\end{array}$ & $\begin{array}{c}\left(S_{w}{ }^{* *}\right)_{m} \\
\%\end{array}$ \\
\hline $0.3 \sim 1.0$ & $0.2 \sim 2.0$ & $0 \sim 10$ & $30 \sim 70$ & $90 \sim 98$ & $5 \sim 30$ & $60 \sim 90$ & $30 \sim 50$ \\
\hline
\end{tabular}

行った結果, 図 6 に示すように全坑井の平均産出ガス水 比が実測值に概ね近似された。この場合眝留層の初期圧 力 p in. $=90 \mathrm{kgf} / \mathrm{cm}^{2 * 1)}$, 泥岩層における初期ガス飽和 率 $\left(S_{\text {gin. }}\right)_{\mathrm{m}}=50 \%$, 眇岩層の厚さ $H_{s}=0.5 \mathrm{~m}$, 泥岩層の 厚さ $H_{m}=0.3 \mathrm{~m}$, 砂岩層之泥岩層の枚数は之も に $N=100$, その他のパラメー夕は $\left(\mathrm{S}_{\mathrm{w}}{ }^{*}\right)_{\mathrm{m}}=80 \%$, $\left(S_{w^{* *}}\right)_{m}=40 \%,\left(S_{w^{*}}\right)_{s}=95 \%,\left(S_{w^{* *}}\right)_{s}=20 \%$ であ る。なお，この場合の計算值と実測值の間の相関係数は 0.97である。

以上の結果から, 本数学モデルは茂原型水溶性ガス眝 留層に打ける群井系の産出挙動を予測するのに妥当であ ると考えられる。

\section{2 坑井間の相互干渉}

群井の最む簡単な例として，図 $2 \mathrm{a}$ に示すように 2 坑 の生産井が同時に採水を行う場合の計算結果を述へ，生 産井 1 における坑底圧力 $\mathrm{P}_{\mathrm{wf} 1}$, 産出ガス水比 $\mathrm{GWR}_{1}$ に 与える生産井 2 の距離之採水量の影響について検討する。

ここで, 計算領域を $\mathrm{L}_{\mathrm{x}}=\mathrm{L}_{\mathrm{y}}=3000 \mathrm{~m}$ とし，格子間隔 を $\Delta x=\Delta y=100 \mathrm{~m}$, 時間ステップ $\Delta t$ を 5 days, 泥岩 層の厚さ $H_{m}$ を $2.2 \mathrm{~m}$, 砂岩層の厚さ $H_{s}$ を $0.8 \mathrm{~m}$, 砂岩 層之泥岩層の枚数 $N$ を屯に 90 , 貯留層の初期圧力 $p_{\text {in. }}=50 \mathrm{kgf} / \mathrm{cm}^{2 * 1)}$, 泥岩層内のガスの初期飽和率 $\left(\mathrm{S}_{\mathrm{gin} .}\right)_{\mathrm{m}}$ を50\%とした。砂岩層および泥岩層はともに等 方均質的であるとし，その孔隙率扰よび絶対浸透率は表 1 に示した值を用いた。

図 7 および図 8 は，不透水境界条件（式(5)）の下で生 産井 1 の採水量 $Q w 1$ を一定 $\left(220 \mathrm{~m}^{3} / \mathrm{d}\right)$ とし, 生産井 2 の距離・採水量比 $\left(L_{\omega} / Q_{w 2}\right)$ をそれぞれ $\infty, 5.5$, $2.7,1.8 \mathrm{~d} / \mathrm{m}^{2}$ としたときの生産井 1 の坑底压力 $p_{w f 1}$ および産出ガス水比 $G W R_{1}$ の時間的変化の計算結果を 示している。図 7 は生産井 2 の採水量 $Q w 2$ を一定 (220 $\left.\mathrm{m}^{3} / \mathrm{d}\right)$ とし坑井間隔を変化した場合 $\left(L_{w} / Q_{w 2}=\infty\right.$, $\left.5.5,2.7,1.8 \mathrm{~d} / \mathrm{m}^{2}\right)$ の結果であり, 図 8 は坑井間隔 $L w$ を一定 $(600 \mathrm{~m})$ とし生産井 2 の採水量 $Q w 2$ 考変化 した場合 $\left(L_{w} / Q_{w 2}=\infty, 5.5,2.7,1.8 \mathrm{~d} / \mathrm{m}^{2}\right)$ の結果 である。

図7，図8の結果から,Qw2 の増大または $L_{w}$ の減少 に伴い生産井 1 の圧力ドローダウン $\Delta p_{w 1}$ と産出ガス 水比 $G W R_{1}$ 加增加している。これは生産井間の相互干 渉によるものである。Lw $Q_{w 2}$ の值が小さくなると，

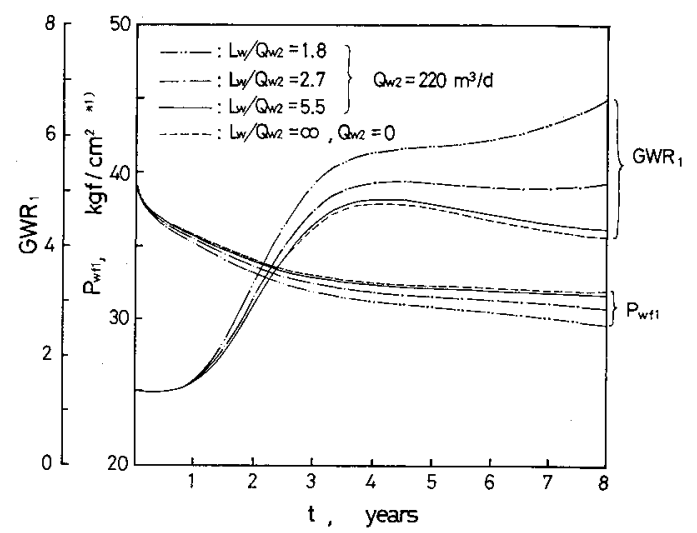

図 7 坑井間隔の変化による影響 $\left(Q w 1=220 \mathrm{~m}^{3} / \mathrm{d}\right)$

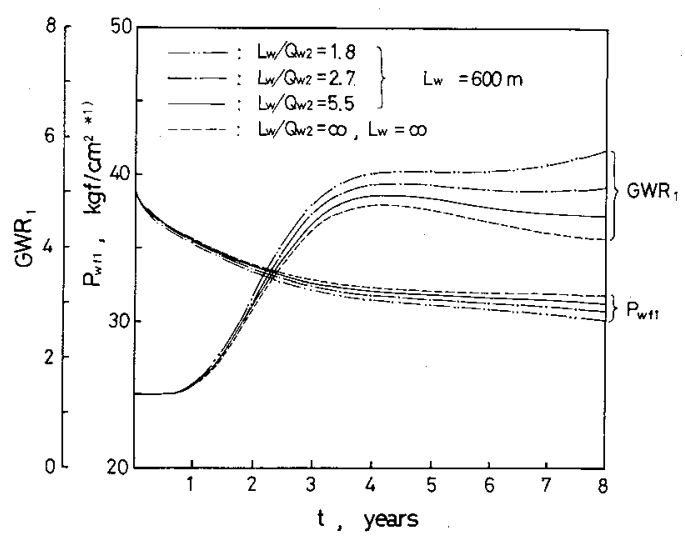

図 8 干渉井採水量の変化による影響 $\left(Q_{w 1}=220 \mathrm{~m}^{3} / \mathrm{d}\right)$

図7に抢引る $L w / Q w_{2}$ の減少による $G W R_{1}$ の増加量 と $p_{w f 1}$ の減少量が図 8 に扔けるそれらの量より大きく なっている。つまり, 距離・採水量比が小さくなると, 生産井 (生産井 1) の産出挙動に与える干涉井 (生産井 2 ) の坑井間隔の変化による影響が採水量の変化による 影響よりも大きいと言える。

\section{7. 断層からのガス供給の影響}

断層からのガスが供給される場合の産出挙動への影響 を検討するために, 図 $2 \mathrm{a}$ に示す生産領域が断層で用ま れていて, 断層からは多量の遊離ガスを含有している水 


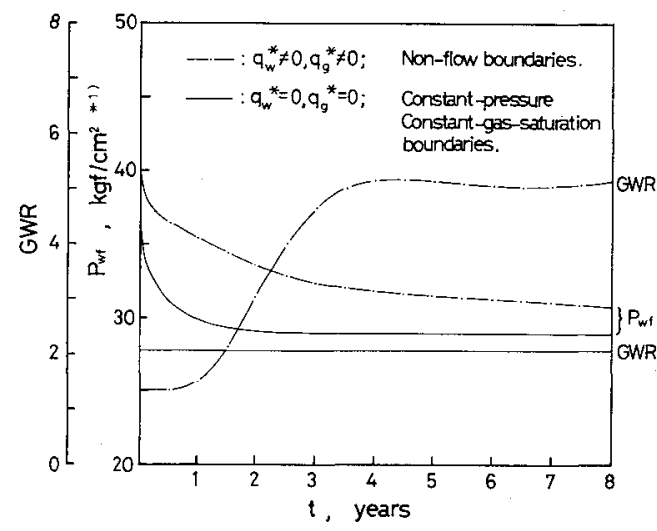

図 9 断層からのガスの供給による影響

が常に十分供給されるるのと仮定して次の計算条件の下 で計算を行った。

前述の流動方程式（式(1)，式(2)）を解くとき，泥岩 層からのガスおよび水の浸出を考慮しない（ $q w^{*}=0$, $\left.q_{g}{ }^{*}=0\right)$ で, 境界条件として式(6)を採用した。ここで, $\left.p_{\text {in. }}=50 \mathrm{kgf} / \mathrm{cm}^{2} * 1\right), \quad\left(S_{\text {gin. }}\right)_{s}=5 \%, L_{x}=L_{y}=3000$ $\mathrm{m}, \Delta x=\Delta y=100 \mathrm{~m}, L_{w}=600 \mathrm{~m}, H_{s}=0.8 \mathrm{~m}, Q_{w 1}=$ $Q w 2=220 \mathrm{~m}^{3} / \mathrm{d}$ を用い, 境界上のガ ス 飽和率 $S_{g b}$ を 45 \%と与えた。

この計算結果と同様な計算条件の下で泥岩層からのガ スおよび水の浸出を考虑した計算結果との比較を図 9 に 示す。これより $45 \%$ という多量の遊離ガスを含む水が常 に境界断層から供給されているにもかかわらず，生産井 からの産出ガス水比が約 2 程度で時間の経過とともに横 ばい状態となり，いわゆる通常型ガス田の産出挙動と同 じ傾向を呈していることが明らかになった。

\section{8. まと}

本研究では茂原型水溶性ガス田の群井系の産出挙動を 予測するために，泥岩層内にガスおよび水の鉛直流，秒
岩層内にガスおよび水の水平二次元流があるとする数字 モデルを構築した。実際の茂原型ガス田における各坑井 の産出ガス水比の平均值についてヒストリマッチングを 行った結果，モデルの妥当性が確からられた。

眝留層が等方均質という条件の下では，2坑井間の相 互干渉の計算例から, 生産井の産出挙動に与える坑井間 隔の変化による影響は, 坑井間隔と採水量の比が小さい と, 採水量の変化による影響よりあ大きいことが明らか になり，境界上において圧力が一定に維持され，境界に 推定された断層から多量の遊離ガスが供給されても，眝 留層はいわゆる通常型ガス田と同様な産出挙動を示すこ とが明らかになった。

\section{参考 文 献}

秋林 智, 周 萍, 1985 : 水溶性ガス田の産出挙動シ ミュレーション, 日本地下水学会誌, 27 (4), 183-190. 秋林 智, 周 萍, 1986 : 茂原型水溶性ガス田におけ る産出挙動の予测モデル, 石油技術協会誌, $51(6)$, 10-15.

COREY, A.T., 1954: The Interrelation between Gas and Oil Relative Permeabilities, Producers Monthly, 19, 38-41.

Frick, T.C., 1962: Hydrocarbon-Water and Formation Water Correlations, Petroleum Production Handbook, vol. II SPE, AIME, 10-10.

MACAIN, W.D. JR, 1973: The Properties of Petroleum Fluids, Pennwell Books, Tulsa, 284. PEACEMAN, D.W., 1978: Interpretation of WellBlock Pressures in Numerical Reservoir Simulation, SPEJ, June, 1978, 183-194.

東京天文台編, 1987: 理科年表, 441 .

上野 道隆・椎名 清 - 本間 敏大 - 品田芳二郎 - 樋 口 鋀, 1964: 茂原型ガス田の最近の開発事情と2・ 3 の問題点，石技誌，29(1)，39-47. 